\title{
Introducing LIR (Lithotheque Ireland), a reference collection of flaked stone tool raw materials from Ireland
}

\author{
Killian Driscoll ${ }^{1,2}$, Adrian L. Burke ${ }^{2}$, Graeme M. Warren ${ }^{1}$ \\ 1. School of Archaeology, University College Dublin. Newman Building, Belfield, Dublin 4, Ireland. \\ Email: Driscoll: killiandriscoll@gmail.com; Warren: graeme.warren@ucd.ie \\ 2. Département d'anthropologie, Université de Montréal. Pavillon Lionel-Groulx, 3150 Jean-Brillant, Montreal, \\ Canada. Email: Burke: adrian.burke@umontreal.ca
}

\begin{abstract}
:
The LIR (Lithotheque Ireland) reference collection of flaked stone tool raw materials from Ireland began in 2013, and is based on the geological prospection from two projects. The first (20132015) focused attention primarily on Carboniferous cherts from the northwest of Ireland, collecting 405 samples. The second (2015-2017) is currently collecting samples of the Cretaceous flint primarily from in situ contexts in the northeast of Ireland, but also includes beach surveys of Cretaceous flint from around the island; the first phase of geological prospection in Autumn 2015 collected 239 samples, with the geological prospection continuing in 2016. Therefore, to date the collection contains over 600 hand samples of chert and flint, along with a small number of other materials (siliceous limestone, tuff, mudstone). The physical reference collection is housed at the UCD School of Archaeology, University College Dublin and contains the geological hand samples along with the various thin sections of the samples that are used for petrographic analysis. The physical collection is complemented by an online database that is to be used alongside the physical collection, or can be used as a stand-alone resource. This paper provides an overview of the database's metadata and the processes of data entry and editing, to serve as a reference point for the database and the fieldwork undertaken to date, and to serve as a template for other researchers undertaking similar work on lithic reference collections.
\end{abstract}

Keywords: archaeology; chert; database; geology; Ireland; lithics; lithotheque; provenancing; raw materials

\section{Introduction}

The LIR (Lithotheque Ireland) (Driscoll 2016a) reference collection of flaked stone tool raw materials from Ireland began in 2013, and is based on the geological prospection from two projects. The first (2013-2015) focused attention primarily on Carboniferous cherts from the northwest of Ireland, collecting 405 samples. The second (2015-2017) is currently collecting samples of the Cretaceous flint primarily from in situ contexts in the northeast of Ireland, but also includes beach surveys of Cretaceous flint from around the island; the first phase of geological prospection in Autumn 2015 collected 239 samples, with the geological

Published by the School of History, Classics and Archaeology, University of Edinburgh ISSN: 2055-0472. URL: http://journals.ed.ac.uk/lithicstudies/

This work is licensed under a Creative Commons Attribution 2.5 UK: Scotland License. 
prospection continuing in 2016. Therefore, to date the collection contains over 600 hand samples of chert and flint, along with a small number of other materials (siliceous limestone, tuff, mudstone). The physical reference collection is housed at the UCD School of Archaeology, University College Dublin and contains the geological hand samples along with the various thin sections of the samples that are used for petrographic analysis. The physical collection is complemented by an online database that is to be used alongside the physical collection, or can be used as a stand-alone resource.

What follows provides an overview of the database's metadata and the processes of data entry and editing, to serve as a reference point for the database and the fieldwork undertaken to date, and to serve as a template for other researchers undertaking similar work on lithic reference collections, especially those that are based on searchable or queryable relational databases and are intended for online consultation and use (for other online lithotheques see, for example, Biró \& Telcs 2000; Burke 2016; Mangado 2016).

\section{Lithotheque organisation}

\subsection{Flaked stone tool raw materials naming conventions - flint, chert, cherty limestone, siliceous limestone}

As has been discussed by Luedtke (1992), there is often considerable confusion as to what distinguishes flint and chert, with these terms sometimes used to define a given rock type based on colour and quality, with some going as far as to use the term flint for artefacts and chert for the raw material, while some regard flint as a variety of chert, and some regard chert as a variety of flint. The word flint has a much older usage in the English language, derived from Old English, whereas chert is first noted in the 17th century (Luedtke 1992). Chert is more commonly used in North America, while flint and chert are distinguished in Europe. Therefore, flint is more ingrained in our language and mind-set as a material for prehistoric tools: the terms 'flintknapping' and 'flintknapper' are commonly used, but we never use 'chertknappers' or 'chertknapping'.

Looking at the broad geology of Ireland, in terms of chert and flint we have two main contexts (Figure 1). Firstly, there are the Carboniferous rocks which cover a large expanse of Ireland (Waters et al. 2011), with some of their constituent rock units providing what in Ireland is called chert. Secondly, there is the Cretaceous deposits found in situ in the northeast that contain what in Ireland is usually called flint or Antrim flint. This is akin to the British chalk flint, but the chalk is much harder, and formed as the Ulster White Limestone Formation (UWL); this was previously more extensive, but survives today mainly along the Antrim coast partly due to the basalt cap that protected it from erosion (Simms 2000). Along with the flint in the Ulster White Limestone, there is redeposited flint within the 'clay with flints', a deposit related to a palaeokarst and palaeosol in between the Cretaceous UWL and the Lower Basalt Formation of the Paleocene (Simms 2000). Along the coast - mainly along the east but some spots along the west - Figure 1 indicates that beach flint is available, with flint also available inland in the glacial till. Compared to the 'Antrim flint', the chert is generally more opaque, and generally ranges from black to grey, but with the cherts also ranging to whites in some places (e.g. Ó Ríordáin 1967), and some being more translucent than much of the flint, e.g., some of the chert from the Bricklieve Limestone Formation (upper) at Carrowkeel, County Sligo.

In the context of archaeology in Ireland, as discussed previously (Driscoll 2009), a significant bias towards flint in the literature from the beginnings of antiquarianism has meant that the role of non-flint materials in the stone tool repertoires of prehistoric communities had been down played, and chert has been considered the poor cousin of flint (see also Little 2009). For example, the use of chert, and lack of in situ sources of flint, in the northwest 
Ireland had been seen as a reason for the surmised early adoption of metal in that region in prehistory (MacAlister 1949). The flint sources in the northeast of the island were seen as a major attractor for the Post-glacial settlers to Ireland; indeed, not only was flint seen as an attractor, but during the Late Glacial period the lack of flint in the south of Ireland was seen as a reason for the perceived avoidance of the area (Movius 1942). More recently, some authors still maintain this misconception of flint being a higher quality material than chert (Costa \& Sternke 2009; Kador 2007), with interpretations of the archaeological record coloured by this dichotomy of flint and chert as good and bad.

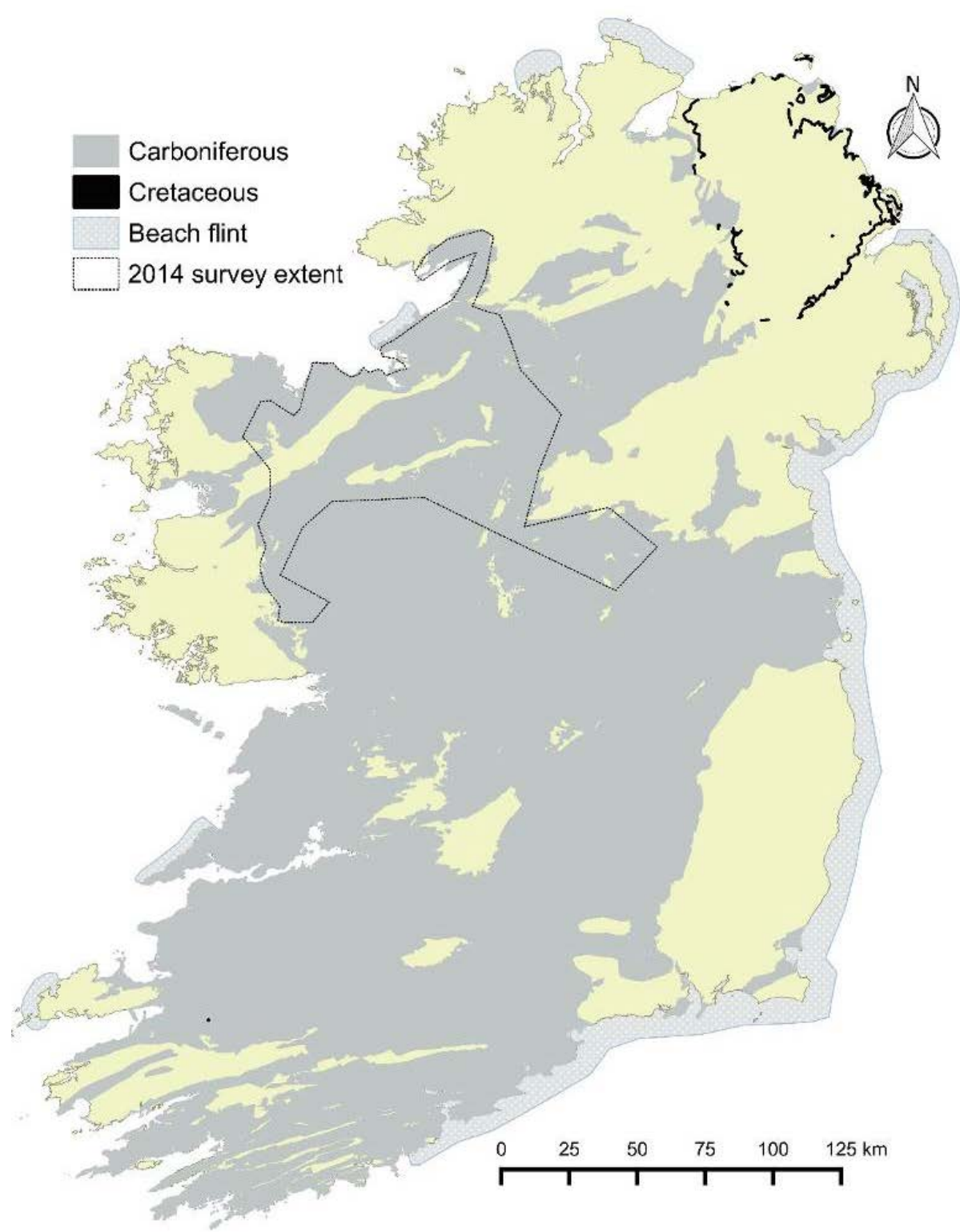

Figure 1. Simplified geology of Ireland in terms of chert and flint deposits. Carboniferous layer from the Geological Survey of Ireland 1:1,000,000 digital data (GSI 2006a); Cretaceous layer from the Geological Survey of Northern Ireland 1:10,000 digital data (GSNI 2015); beach flint layer adapted from Woodman et al. (2006).

While in broad generalities such a dichotomy may work in that the flint deposits in the northeast of the island often contain high quality nodules, and the chert deposits in the carboniferous basin across much of the country are often of lesser quality, this distinction rapidly breaks down when the various deposits are examined at a local or sub-regional levels - levels at which prehistoric communities would have lived and worked. While as far back as 
1983 Griffiths and Woodman $(1987,249)$ noted in their presentation of preliminary results of provenancing of Cretaceous chert from Ireland that "Cretaceous flint ([is] now usually referred to as chert)", it would appear that the using term 'chert' is in fact unusual for describing the Cretaceous flint in Ireland, and the archaeological and geological communities continue with flint - therefore, the LIR lithotheque retains this usage; following Luedtke (1992), we would argue that in the context of the geology and archaeology of Ireland, the term 'chert' can be used as a general term for sedimentary fine-grained siliceous rocks, with flint considered a variety of chert which is provenanced to Cretaceous rocks, but with no connotations regarding colour or quality.

In addition, we have added to our terminology the category of siliceous limestone. This is a field geology term used to name fine grained limestone that breaks conchoidally and that appears to have a high silica content. This material is distinguished from replacement chert nodules found in the limestone that are clearly distinct from the host rock. The siliceous limestone is not micrite (fine grained carbonate mud) and is not to be confused with terms used be geologists like cherty limestone which often refers to limestone with a lot of distinct chert nodules or beds. Finally, the petrography and geochemistry of this category of siliceous limestone may help to define it as a useful rock making stone tools in the past but this has to be compared to actual archaeological collections in order to see if the material was used. Occasionally, siliceous limestone can take a nodular form, thus also appearing distinct from the host rock, such as in outcrops of mudbank limestone in the Dartry Limestone Formation, Lough Gill, County Sligo. This is not a common feature, but it does reinforce the fact that there is no sharp division between limestone and chert.

\subsection{Physical collection}

The physical collection is housed at the School of Archaeology in University College Dublin, and is comprised of the 641 geological hand samples collected to date from the two projects mentioned in the introduction, with the second project's geological prospection still ongoing. A further number of hand samples have been included from previous projects, specifically samples of silicified dolomite from Lough Allen, County Leitrim collected during a project on a primarily Mesolithic assemblage from the lake (Driscoll et al. 2014); and hand samples of vein quartz from Belderrig, County Mayo collected during a project on quartz technology in Ireland (Driscoll 2011; Driscoll \& Menuge 2011). The collection also includes the various thin sections made of the samples during these four projects. As the collection includes a number of surficial samples, it is physically organised by country and county rather than by rock unit, with each sample's label including brief information regarding its type, material, provenance etc., with the full details located in the online database that is designed to be used alongside the physical collection or as a stand-alone resource.

\subsection{Online database}

As mentioned, the online database is designed to be used alongside the physical collection or as a stand-alone resource. The project is using PostgreSQL (2015) an Open Source object-relational database system, and PostGIS a spatial database extender for PostgreSQL. These are integrated with QGIS (2014) an Open Source Geographic Information System, and OpenStreetMap (OSM 2016) an Open Data base map dataset, with Microsoft Access used as an additional front end for data entry (specifically for entering data via forms for entering parent-child records). Data is also entered and edited directly with QGIS or through the PostgreSQL database itself.

The online database is constructed using PHP (Figure 2), with the interactive maps produced with Leaflet (Agafonkin 2016), an Open Source JavaScript library for interactive 
maps. The online database allows users to avail themselves of advanced search and filter options of the survey points, samples, geological rock units, and images to facilitate the searches for survey points and samples with or without specific characteristics. Users can also print or export the records in a variety of formats (Excel, csv, pdf, xml, Word). Figure 2 presents a screenshot of the online database, as viewed from the Survey points master records; from the Survey point master record, the related samples, images, and so forth can be viewed below each record in tabbed form. The data can also be accessed in reverse, by viewing and searching the records via the Samples as master records, while the database can be searched via the images, and the images can also be browsed in an image gallery. Finally, the database contains a glossary of terms used throughout the database, a reference section of literature directly cited as well as related literature, and an outline of the database's metadata, with the latter summarised here in Section 2.4.

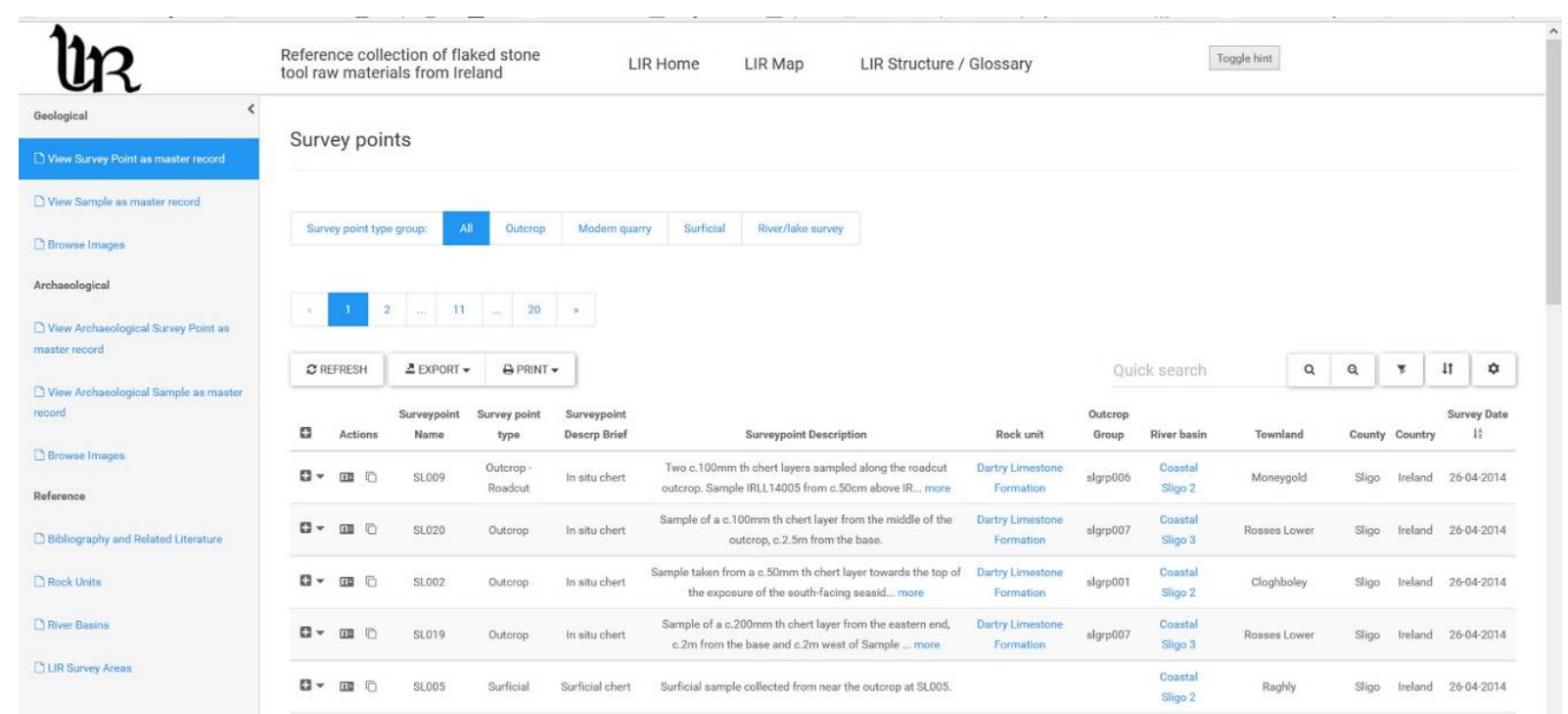

Figure 2. Screenshot of the LIR online database as viewed from the survey points' main page (Driscoll 2016b). (See this link.)

\subsection{Lithotheque and database structure}

The data collected during the geological prospection and subsequent analysis of the materials is stored in 29 principal tables, with Figure 3 providing an overview of the tables and their relationships, and Table 1 listing the principal tables, with which the following subsections of Section 2.4 are based. The data is based around the geological component's survey points table and samples table. These are matched with the archaeological component's survey points table and samples table - while the physical collection does not include archaeological samples (as these are returned to the respective owners after analysis), their related data can be viewed within the online database. What follows provides an overview of the database's metadata and the processes of data entry and editing, to serve as a reference point for database and the fieldwork.

\subsubsection{Areas and localities}

In order to sub-divide the regional surveys' extents into meaningful sub-regions, the regions were divided into 'Areas', with these areas' borders based on a combination of topographical, geological, and hydrological factors. To date, 65 areas are included in the database, which are represented as polygon features within the spatial layers. Of these 65, 62 are based on the geological prospection (Figure 4) along with 3 that contain the 
archaeological case study sites used, but where no geological prospection was undertaken (as they lie in areas with bedrock with no in situ chert). Within each area, the extent surveyed was further divided into 'Localities', with the localities serving as the locations of a group of survey points taken; the localities are represented as point features within the spatial layers, and the Localities data includes a brief description of the Locality. To date the 65 Areas hold 234 Localities, of which 9 are archaeological case study localities. While the survey points' coordinates were collected in the field (see below), the Area polygons and the Locality points were added in QGIS after the survey points were imported, thus providing the post-fieldwork grouping of the fieldwork. The Area table includes the Area name, which is a descriptive name based on a main feature of the area such as hill, lake, settlement etc., while the Locality table contains a descriptive name based on local name or feature such as townland, hill, river etc., as well as a brief description of the locality surveyed (Table 2).

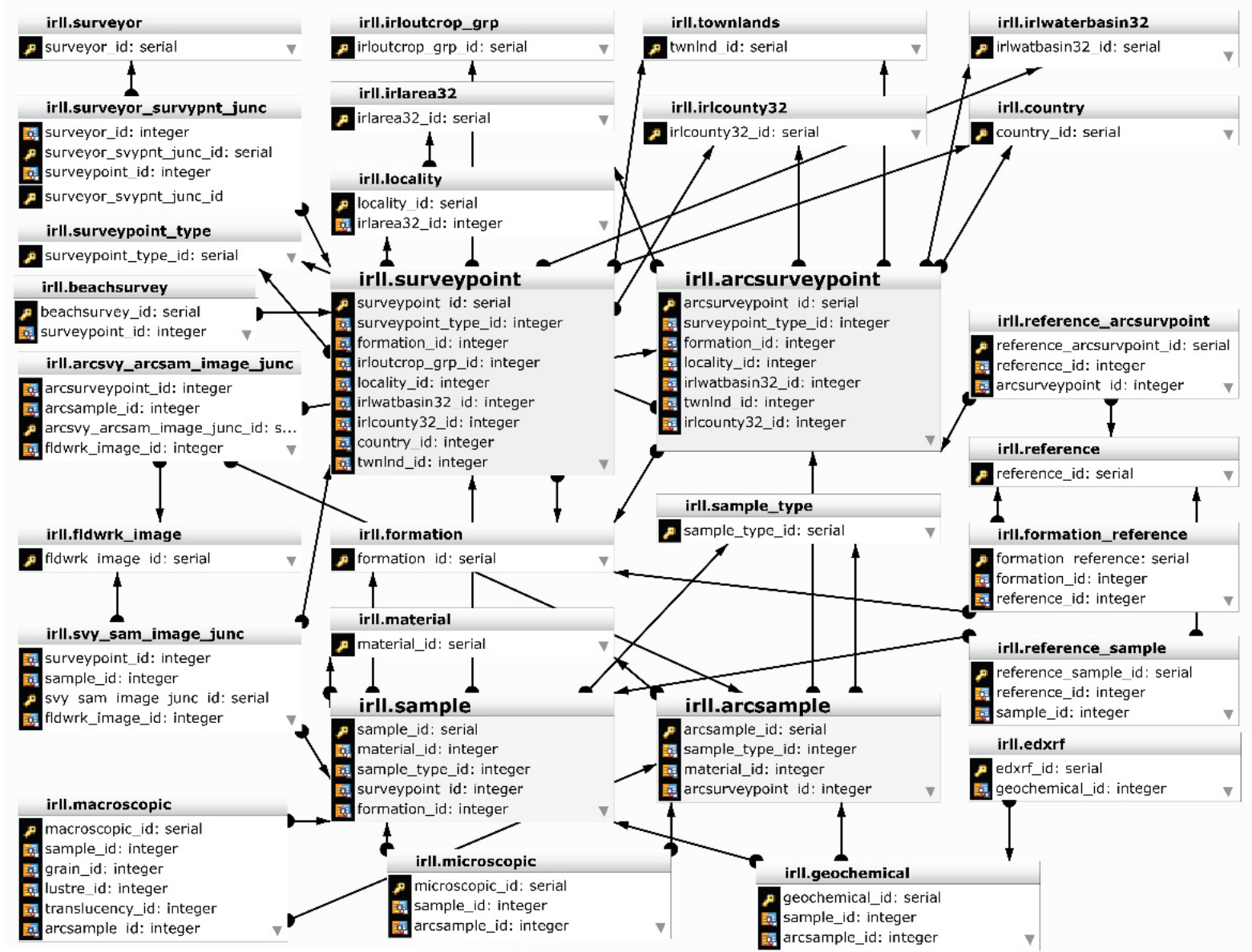

Figure 3. Overview of the LIR database principal tables and their relationships. 
Table 1. List of the principal tables of the database, with the database table names as they appear in Figure 3 in brackets.

\begin{tabular}{|c|c|c|c|}
\hline Table (table name) & $\begin{array}{l}\text { Article } \\
\text { Section }\end{array}$ & $\begin{array}{l}\text { GIS Data } \\
\text { Type }\end{array}$ & Description \\
\hline Area (irlarea32) & 2.4.1. & Polygon & $\begin{array}{l}\text { A sub-division of the regional surveys' extents into } \\
\text { meaningful sub-regions, with these areas' borders based } \\
\text { on a combination of topographical, geological, and } \\
\text { hydrological factors }\end{array}$ \\
\hline Locality (locality) & 2.4.1. & Point & $\begin{array}{l}\text { Within each area, the extent surveyed was further divided } \\
\text { into 'Localities', serving as the locations of a group of } \\
\text { survey points taken }\end{array}$ \\
\hline $\begin{array}{l}\text { Survey point } \\
\text { (surveypoint) }\end{array}$ & 2.4 .2 & Point & $\begin{array}{l}\text { The base level of GPS recording for the geological } \\
\text { prospection }\end{array}$ \\
\hline $\begin{array}{l}\text { Beach survey } \\
\text { (beachsurvey) }\end{array}$ & 2.4.2. & & Additional survey point data related to the beach surveys \\
\hline $\begin{array}{l}\text { Survey point type } \\
\text { (surveypoint_type) }\end{array}$ & 2.4.2. & - & $\begin{array}{l}\text { Look up table for survey point types (geological and } \\
\text { archaeological) }\end{array}$ \\
\hline Surveyors (surveyor) & 2.4.2. & - & $\begin{array}{l}\text { Name of surveyor(s), linked via a junction table } \\
\text { (surveyor_survpoint_junc) }\end{array}$ \\
\hline $\begin{array}{l}\text { Outcrop group } \\
\text { (irloutcrop_grp) }\end{array}$ & 2.4.3. & Polygon & $\begin{array}{l}\text { The survey points along a continuous or discontinuous } \\
\text { outcrop were recorded and grouped as an outcrop group }\end{array}$ \\
\hline Rock unit (formation) & 2.4.4. & Polygon & $\begin{array}{l}\text { The bedrock of the survey point or sample, based on, } \\
\text { based on GSI (2006b) and GSNI (2015) data }\end{array}$ \\
\hline $\begin{array}{l}\text { River Basin } \\
\text { (irlwaterbasin32) }\end{array}$ & 2.4.4. & Polygon & $\begin{array}{l}\text { The river basin of the survey point, based on EPA (2015) } \\
\text { data }\end{array}$ \\
\hline $\begin{array}{l}\text { Townland } \\
\text { (townlands) }\end{array}$ & 2.4.4. & Polygon & $\begin{array}{l}\text { The smallest administrative unit used in Ireland, based on } \\
\text { OSM (2016) data }\end{array}$ \\
\hline County (irlcounty32) & 2.4.4. & Polygon & Administrative unit, based on OSM (2016) data \\
\hline Country (country) & 2.4.4. & - & Country of survey point \\
\hline Sample (sample) & 2.4.5. & - & Contains primary information of geological samples \\
\hline $\begin{array}{l}\text { Sample type } \\
\text { (sample_type) }\end{array}$ & 2.4.5. & - & $\begin{array}{l}\text { Look up table for sample type (geological and } \\
\text { archaeological) }\end{array}$ \\
\hline Material (material) & 2.4.5. & - & $\begin{array}{l}\text { Look up table for sample material (geological and } \\
\text { archaeological) }\end{array}$ \\
\hline $\begin{array}{l}\text { Macroscopic } \\
\text { (macroscopic) }\end{array}$ & 2.4.5. & - & $\begin{array}{l}\text { Macroscopic data of samples (geological and } \\
\text { archaeological) }\end{array}$ \\
\hline $\begin{array}{l}\text { Microscopic } \\
\text { (microscopic) }\end{array}$ & 2.4.5. & - & $\begin{array}{l}\text { Microscopic - petrographic data of samples (geological } \\
\text { and archaeological) }\end{array}$ \\
\hline $\begin{array}{l}\text { Geochemical } \\
\text { (geochemical) }\end{array}$ & 2.4.5. & - & $\begin{array}{l}\text { Table linking to the various types of geochemical analysis } \\
\text { of samples (geological and archaeological) }\end{array}$ \\
\hline ED-XRF (edxrf) & 2.4.5. & & ED-XRF data of samples (geological and archaeological) \\
\hline $\begin{array}{l}\text { Images } \\
\text { (fldwrk_image) }\end{array}$ & 2.4.6. & - & $\begin{array}{l}\text { Images data, linked via junction tables for geological } \\
\text { survey points and samples (svy_sam_image_junc) and } \\
\text { archaeological survey points and samples } \\
\text { (arcsvy_arcsam_image_junc) }\end{array}$ \\
\hline $\begin{array}{l}\text { Archaeological survey } \\
\text { point } \\
\text { (arcsurveypoint) }\end{array}$ & 2.4.7. & Point & $\begin{array}{l}\text { Similar to the geological survey point table, the base level } \\
\text { of recording the archaeological sites }\end{array}$ \\
\hline $\begin{array}{l}\text { Archaeological } \\
\text { sample (arcsample) }\end{array}$ & 2.4.7. & - & Contains primary information of archaeological samples \\
\hline Reference (reference) & - & - & $\begin{array}{l}\text { Literature references linked via junction tables for rock } \\
\text { units (formation_reference), geological samples } \\
\text { (reference_sample), and archaeology survey points }\end{array}$ \\
\hline
\end{tabular}


(reference_arcsurveypoint)

Table 2. Summary and description of the attributes in the tables of Area, Locality, Survey point, Survey point type, Surveyors, and Outcrop group.

\begin{tabular}{|c|c|c|}
\hline Table & Attribute & Description \\
\hline Area & Name & $\begin{array}{l}\text { Descriptive name based on a main feature of the area such as } \\
\text { hill, lake, settlement etc. }\end{array}$ \\
\hline \multirow[t]{2}{*}{ Locality } & Name & $\begin{array}{l}\text { Descriptive name based on local name or feature such as } \\
\text { townland, hill, river etc. }\end{array}$ \\
\hline & Description & Brief description of the locality surveyed \\
\hline \multirow[t]{4}{*}{$\begin{array}{l}\text { Survey } \\
\text { point }\end{array}$} & Name & $\begin{array}{l}\text { Project code identifier - a prefix based on the County name } \\
\text { followed by a numeric sequence, e.g., LM001 }\end{array}$ \\
\hline & Description & $\begin{array}{l}\text { A description of the survey point and the relationships to the } \\
\text { samples taken if applicable }\end{array}$ \\
\hline & $\begin{array}{l}\text { Brief } \\
\text { description }\end{array}$ & $\begin{array}{l}\text { Used to group the survey points into varying kinds and is akin to } \\
\text { an extension of the survey point types data }\end{array}$ \\
\hline & Date & Date of survey \\
\hline $\begin{array}{l}\text { Beach } \\
\text { survey }\end{array}$ & (Various) & $\begin{array}{l}\text { Contains additional data related to the survey point for the } \\
\text { beach surveys, including area surveyed (in } \mathrm{m} 2 \text { ); direction of } \\
\text { transect surveyed; roundness scale and size range of the pebbles } \\
\text { or cobbles; total finds; total weight and mean weight; and a } \\
\text { breakdown of percentages of finds per } \mathrm{m} 2 \text {, totals and } \\
\text { percentages per size ranges, and percentages per roundness } \\
\text { scale }\end{array}$ \\
\hline \multirow[t]{2}{*}{$\begin{array}{l}\text { Survey } \\
\text { point } \\
\text { type }\end{array}$} & Group & $\begin{array}{l}\text { The survey points are divided into } 5 \text { main types: outcrop, } \\
\text { modern quarry, surficial, river or lake, beach. The survey points } \\
\text { from modern quarries were treated separately from outcrops, } \\
\text { because the quarry may or may not have been exposed as an } \\
\text { outcrop, and sampling from quarries may be sampling lower } \\
\text { levels of bedrock than would have inaccessible during prehistory } \\
\text { in that actual location. The surficial type includes surficial points } \\
\text { that were surveyed beside or near outcrops, but were not } \\
\text { actually in situ. A sixth type is for the archaeological case study } \\
\text { survey point }\end{array}$ \\
\hline & Name & $\begin{array}{l}\text { Name of the type groups, with a further sub-division of the } \\
\text { outcrop type into outcrops exposed as boulders from blasting of } \\
\text { the bedrock during dredging, roadcuts, and 'close to'; the latter } \\
\text { is used to denote where while the material is effectively in situ, it } \\
\text { has moved slightly or some metres due to slippage or glacial } \\
\text { action (as is the case of the disturbed chert layer which caps } \\
\text { Carrowkeel) }\end{array}$ \\
\hline Surveyors & Name & Name of surveyor \\
\hline \multirow[t]{2}{*}{$\begin{array}{l}\text { Outcrop } \\
\text { group }\end{array}$} & Name & $\begin{array}{l}\text { Project code identifier - a prefix based on the County name } \\
\text { followed by 'grp', and a numeric sequence, e.g., Imgrp001 }\end{array}$ \\
\hline & Description & Brief description of the outcrop group \\
\hline
\end{tabular}




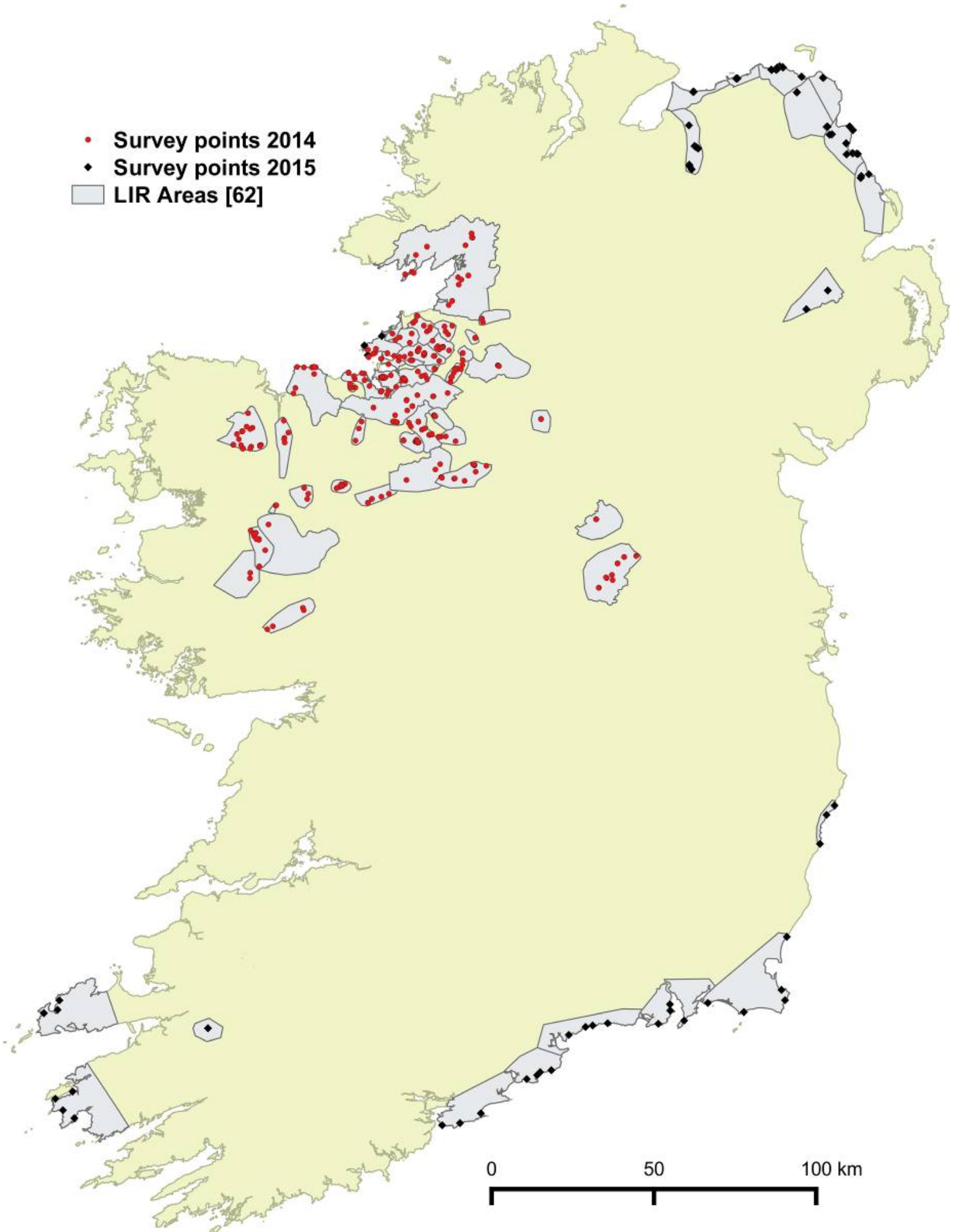

Figure 4. Overview of the LIR Areas surveyed to date, with the 2014 and 2015 survey points marked. 


\subsubsection{Survey points and outcrops}

The Localities are sub-divided into their constituent Survey points (Table 2 and Figure 4), which are the base level of recording for the geological prospection. The survey points were recorded with a Garmin Oregon 650t GPS unit with a reported (manufacturer's) average accuracy of $\sim 5 \mathrm{~m}$. The data was then imported to the database via QGIS. The survey points were linked to their related tables (e.g., river basins, townlands, counties, areas etc.) automatically using the geomnearest or geomwithin functions (Ferreguti 2014) in QGIS; these provided a rapid method of linking the various tables. Each survey point is given a project code identifier - a prefix based on the County name followed by a numeric sequence (e.g., LM001 for the first survey point from County Leitrim). Data is recorded as to the date of the survey, the names of the surveyors, and where applicable the associated rock unit. The survey points include a brief description and an extended description of the survey point, with the brief description used to group the survey points into varying kinds and is akin to an extension of the survey point type described below.

While the geological prospection for the two projects has been based primarily on surveying and collecting geological hand samples from in situ contexts, i.e. outcrops, the collection contains information regarding a variety of contexts, with the survey points divided into five main types:

- outcrops

- exposures in modern quarries

- surficial sample survey points

- river or lake survey points

- beach survey points

As well as the survey points including positive evidence where samples were collected, the database has recorded negative evidence where a given outcrop, river, lake, or beach contained no chert, or at times where no outcrop was found. This negative evidence is an important inclusion as it contextualises the samples in the reference collection in terms of their placement in the landscape and therefore the accessibility and visibility of raw materials.

Data from the beach surveys, which examine the Cretaceous flint beach deposits, is held in a separate table, with 57 attributes. These include the area surveyed (in $\mathrm{m} 2$ ), the direction of the transect surveyed; the roundness scale and size range of the pebbles or cobbles; total finds; total weight and mean weight; and a breakdown of percentages of finds per $\mathrm{m} 2$, totals and percentages per size ranges, and percentages per roundness scale. While some beaches contained hundreds of Cretaceous flint pebbles or cobbles, after the analysis of size range, roundess scale, and weight, a maximum of three per transect surveyed where kept as hand samples for the physical reference collection.

\subsubsection{Outcrop groups}

For the outcrops, the individual survey points along a given outcrop were recorded, and where appropriate, the survey points along a continuous or discontinuous outcrop were recorded and grouped as an outcrop group (Table 1), with each outcrop group also given a project code identifier (e.g., lmgrp001 for the first outcrop group from Leitrim). Therefore, while the 2013-215 project contains over 300 survey points from outcrops, these are related to 170 outcrop groups (Figure 5). Using the tracks recorded with the GPS unit, the approximate outline of the outcrop extents surveyed, usually along strike, were traced as a polygon and stored in the outcrop group table (irloutcrop_grp); for the various outcrops not found, an arbitrary $6 \mathrm{~m} 2$ polygon was drawn in the locality searched. 


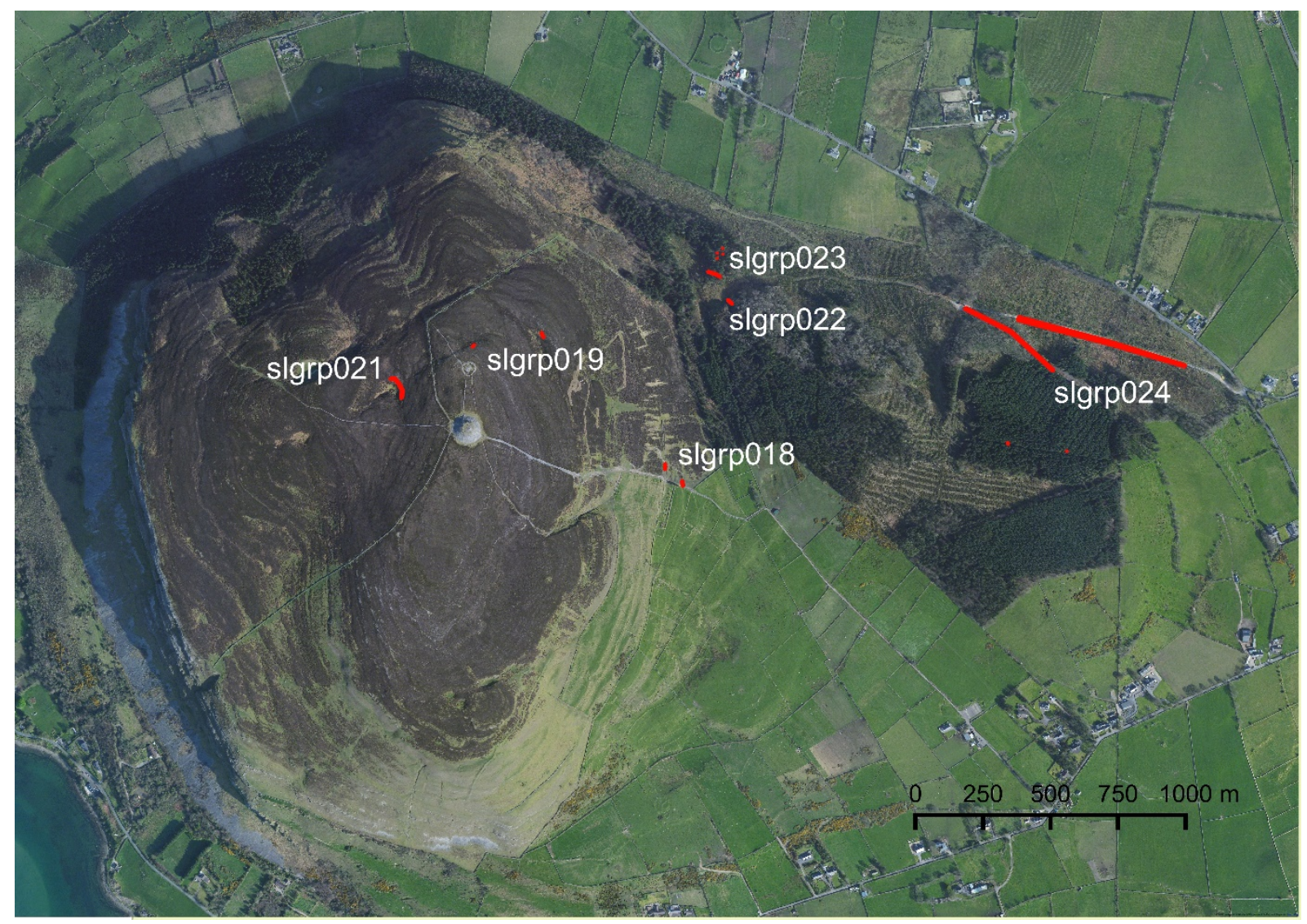

Figure 5. Example of the outcrop group table at Knocknarea and Rathcarrick, County Sligo, where 28 survey points were taken from 7 outcrop groups (slgrp018-24). The passage tomb, Queen Maeve's tomb, on the summit of Knocknarea can be seen in the middle left of the image. Satellite imagery from Microsoft Bing Maps.

\subsubsection{Data from external sources - water basins, rock units, administrative units}

The survey points' table and related tables include digital data from three external sources.

The water basins layer is based on the EPA (Environmental Protection Agency) digital dataset (EPA 2015) which available through a creative commons license (CC BY 4.0), and modified to include names for the numerous coastal locations that do not have official names within the EPA data - these were labelled 'coastal', and for this project, they have been renamed with the county name and a sequential number.

The rock units' data is based on the GSI (Geological Survey of Ireland) 100k digital dataset for the Republic of Ireland (GSI 2006b), and the GSNI (Geological Survey of Northern Ireland) 10k digital dataset for Northern Ireland (GSNI 2015). These two datasets were amended slightly to allow the data to be stored in one table (changing the column headings to match).

The administrative units (townlands and counties) are based on the OSM (OpenStreetMap) data (OSM 2016). When the project began in 2013, we had used the Ordnance Survey Ireland datasets, but as the OSM project has progressed significantly since 2013 in its coverage of administrative units in Ireland (i.e. mapping the over 60,000 townlands (Ireland 2016), we have switched to making use of the Open Data as much as possible. 


\subsubsection{Geological hand samples - macroscopic, microscopic, geochemical}

A given survey point may contain zero to many related samples (as the database contains negative information mentioned above, and occasionally material from a given survey point was not sampled), with the samples table therefore being a child record, with the following attributes: sample name, material, rock unit, and sample type. Each hand sample is given a project code identifier - a prefix based on the project and year followed by a numeric sequence (e.g., IRLL14001 and IRLL15001). The samples are divided into five types: in situ, in situ -close to, scree modern quarry, surficial - glacial erratic, and surficial. A sixth type is for the archaeological samples analysed. As with the survey points, the 'in situ - close to' category is used for material that is effectively in situ, but has moved slightly or some metres due to slippage or glacial action; the surficial category includes hand samples collected from the floors of modern quarries ('scree modern quarry'), and also a number of surficial samples taken from large glacial erratics of the host rock, which distinguishes this type of surficial sample from the smaller blocks of surficial samples which may or may not have been transported glacially. While the rock unit is previously recorded in the survey point parent record, since occasionally surficial samples are collected by an in situ survey point, the sample record contains the actual rock unit if applicable of the sample, and also the material.

The hand samples are linked to their respective macroscopic descriptions in the macroscopic table, and if applicable the microscopic (petrographic) and geochemical tables. Table 4 provides an example of the Macroscopic table's records. For the macroscopic descriptions, up to 14 attributes are recorded. Table 3 provides a summary and description of these 14 attributes. A clarification of how the terms of cortex, weathering rind, and weathered surface are used is presented below.

While in the context of chert and flint in Ireland, it has previously been suggested that "unlike flint, chert has no true cortical surface" (Little 2010: 164 cf. Driscoll 2010; Warren et al. 2009), we would argue that chert can, and does, contain cortex. Following the description from Luedtke (1992: 139), cortex is a diagenetic feature that is the "outer layer found on many cherts which is formed as a transition zone between the chert and its bedrock matrix and which is visually and mineralogically distinct from either"; this transition zone between the chert and the bedrock can be sharp or more gradual (e.g., Figure 6). A further distinction is made between the cortex which is a diagenetic feature, and a weathering rind, and a weathered surface (Figure 6). The weathering rind is the layer that forms on the chert (or on the cortex) through weathering, where the weathering penetrates and alters the material surface; the weathered surface is an altering of the surface, but there is no visible penetration into the rock itself.

\subsubsection{Images}

The database contains to date over 2000 images, with all of the images taken for this project licensed under Creative Commons Attribution-ShareAlike 4.0 International Licenses. The images are processed with Adobe Lightroom and Photoshop, with additional metadata added in Lightroom, including titles, captions, descriptions, keywords, creator information, copyright status etc., with the image filenames amended to contain a project prefix (e.g., irll14_dsc0001). The metadata was then extracted to a .csv file using Exiftools (Harvey 2016), which extracts all image metadata; this was imported as a table to the PostgreSQL database via QGIS (2014) using PostGIS. The fieldwork images were mainly taken with the GPS unit's camera, and therefore were geotagged. For additional non-geotagged images, including the studio images of the hand samples, the GPS coordinates were added in Lightroom, corrected in QGIS, and then updated to the images using Exiftool (Harvey 2016). 
Table 3. Summary and description of the attributes from the Macroscopic table.

\begin{tabular}{|c|c|}
\hline Attribute & Description \\
\hline Host rock & Additional description of the host rock, if applicable \\
\hline Grain & Divided into 3 categories of fine, medium, and coarse \\
\hline Lustre & Divided into 3 categories of matte, medium, and waxy or shiny \\
\hline Translucency & $\begin{array}{l}\text { Divided into } 3 \text { categories of translucent, semi-translucent, and } \\
\text { opaque }\end{array}$ \\
\hline Colour & $\begin{array}{l}\text { Using Munsell chart codes, up to four colours are recorded: } \\
\text { groundmass weathered or unweathered and pattern weathered or } \\
\text { unweathered }\end{array}$ \\
\hline Cortex or exterior surface & $\begin{array}{l}\text { The presence or absence of an exterior surface, which is divided } \\
\text { into cortex, weathering rind, and weathered surface. Cortex is a } \\
\text { diagenetic feature that is the outer layer found on many cherts } \\
\text { which is formed as a transition zone between the chert and its } \\
\text { bedrock matrix and which is visually and mineralogically distinct } \\
\text { from either; this transition zone between the chert and the bedrock } \\
\text { can be sharp or more gradual (Luedtke 1992). The weathering rind } \\
\text { is the layer that forms on the chert (or cortex) through weathering, } \\
\text { where the weathering penetrates and alters the material surface; } \\
\text { the weathered surface is an altering of the surface, but there is no } \\
\text { visible penetration into the rock itself }\end{array}$ \\
\hline Fossil & $\begin{array}{l}\text { The presence or absence of fossils, visible under a microscope up to } \\
40 x \text { magnification; if present a description of the fossil size, } \\
\text { abundance and types }\end{array}$ \\
\hline Mineral & $\begin{array}{l}\text { The presence or absence of minerals, visible under a microscope up } \\
\text { to } 40 x \text { magnification; if present a description of the mineral size, } \\
\text { abundance and types }\end{array}$ \\
\hline Structure & $\begin{array}{l}\text { The presence or absence of structures, visible under a microscope } \\
\text { up to } 40 \mathrm{x} \text { magnification; if present a description, with structure } \\
\text { including e.g., sedimentary layers, compaction, deformation }\end{array}$ \\
\hline Pattern & $\begin{array}{l}\text { The presence or absence of patterning; if present a description, } \\
\text { with patterning including e.g., mottling, laminations, banding, } \\
\text { speckling etc. The pattern is often related to the structure (e.g., } \\
\text { Example IRLL14027) }\end{array}$ \\
\hline Vugs & The presence or absence of vugs (cavities) within the material \\
\hline Joints & $\begin{array}{l}\text { A joint is a crack in a rock along which no displacement has } \\
\text { occurred; with chert is often as the chert is less flexible that the } \\
\text { parent rock, causing fracture. The joints are noted for their } \\
\text { prevalence, and their spacing, with tightly spaced joints being }<4 \\
\mathrm{~cm} \text { apart and widely spaced being }>4 \mathrm{~cm} \text { apart. Figure } 7 \text { presents } \\
\text { examples of joints. }\end{array}$ \\
\hline $\begin{array}{l}\text { Silification gradation } \\
\text { within bed }\end{array}$ & $\begin{array}{l}\text { A description of the degree of silification in the material; this can be } \\
\text { homogeneous, or with a gradation from a denser and more } \\
\text { silicified inner core to a less silicified outer edge, often present as a } \\
\text { more coarse-grained fabric (e.g., Figure } 7)\end{array}$ \\
\hline $\begin{array}{l}\text { Approximate bed } \\
\text { thickness }(\mathrm{cm})\end{array}$ & Thickness of the cherty material \\
\hline
\end{tabular}


Table 4. Example of a Macroscopic table record: Sample IRLL14027 (see Figure 8 for this sample's image record in the database).

\begin{tabular}{ll}
\hline Attribute & Data \\
\hline Host Rock & - \\
Grain & Fine \\
Lustre & Waxy - shiny \\
Translucency & Semi-translucent \\
Colour groundmass unweathered & Dark grey (4/N) \\
Colour groundmass weathered & Grey to light brownish grey (2.5Y6/1-6/2) \\
Colour pattern unweathered & - \\
Colour pattern weathered & - \\
Cortex or exterior surface & Yes \\
Cortex or exterior surface description & Very thin (<1mm) weathered surface \\
Fossil & No \\
Fossil description & - \\
Mineral & Yes \\
Mineral description & Rare sub-mil quartz mineral facets (sparkles) \\
Structure & Yes \\
Structure description & Faint festooning or lamination (pressure-solution) \\
Pattern & Yes \\
Pattern description & Faint festooning or lamination \\
Vugs & No \\
Vugs description & - \\
Joints & Very prevalent, widely spaced (not measured) \\
Silicification gradation within bed & Massive and homogeneous over 10cm \\
Approximate bed thickness (cm) & 10 \\
\hline
\end{tabular}

The data in the image table was linked to the survey point table automatically using the geomnearest expression in QGIS; this provided a rapid method of linking the table, but included errors where the incorrect images were linked due to proximity ambiguities; all the links were therefore checked and corrected as needed. Further, as the images are linked to the survey points in a many to many relationship, the table was also manually amended to create these other links.

Figure 8 provides an example of images and their captions related to Sample IRLL14027, a chert sample collected from the Dartry Limestone Formation in County Sligo; the images from the field include a close-up of the sample, and a wide shot of the outcrop and information regarding any nearby samples; the images also include the hand sample in the reference collection, and, if applicable, an image of the cut and polished chert block used for the XRF geochemical analysis, while others include images of the thin sections used for the microscopic analysis. 

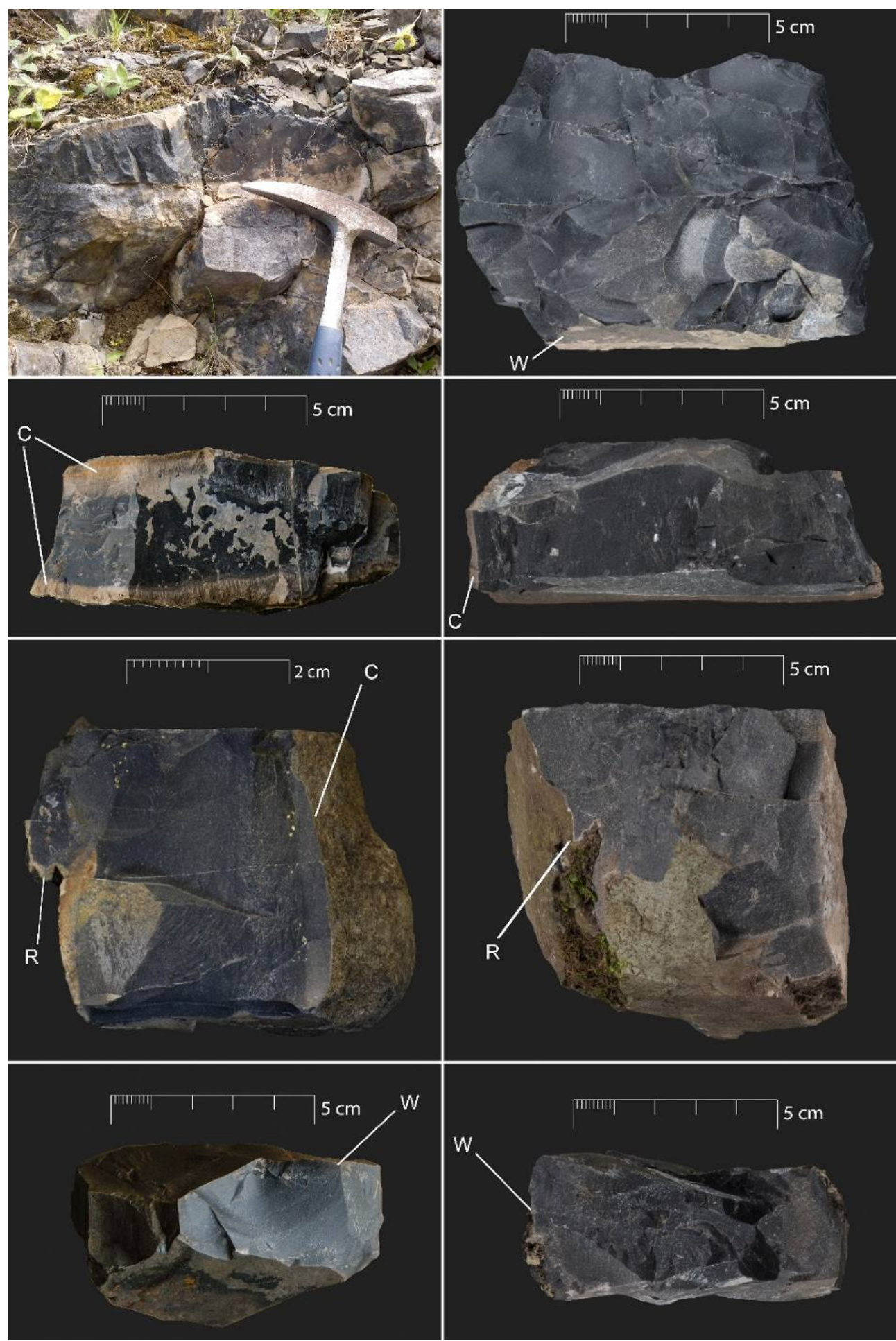

Figure 6. Images taken from the LIR database, with annotations added: $\mathrm{W}=$ weathered surface; $\mathrm{C}=\mathrm{cortex} ; \mathrm{R}=$ weathering rind. Top Left: Sample IRLL14165 (sample above hammer) from Derravaragh Chert, Portnashangan quarry, County Westmeath, showing thicker cortex on top of chert bed, thinner cortex on bottom of chert bed, and weathered surface on vertical face; Top Right: hand sample of IRLL14165, with the vertical weathered surface. 2nd Row Left: Example of thick cortex with a relatively sharp transition zone between cortex and chert (IRLL14022); 2nd Row Right: Example of thin cortex with sharp transition (IRLL14020); 3rd Row Left: Example with thin cortex on right side and weathering rind on left side (IRLL14320); 3rd Row Right: Example with thin weathering rind (IRLL14344); Bottom Left: Example of very thin weathered surface (IRLL14027); Bottom Right: Example with thin weathered surface (IRLL14340). Samples IRLL14020, IRLL14022, and IRLL14027 from the Dartry Limestone Formation, Largandoon, County Leitrim; IRLL14320 from Rinmore, County Mayo (surficial sample); IRLL14344 from the Ballina Limestone Formation (Upper), Rinmore, County Mayo; IRLL14340 from the Ballina Limestone Formation (Upper), Aughris Head, County Mayo. 


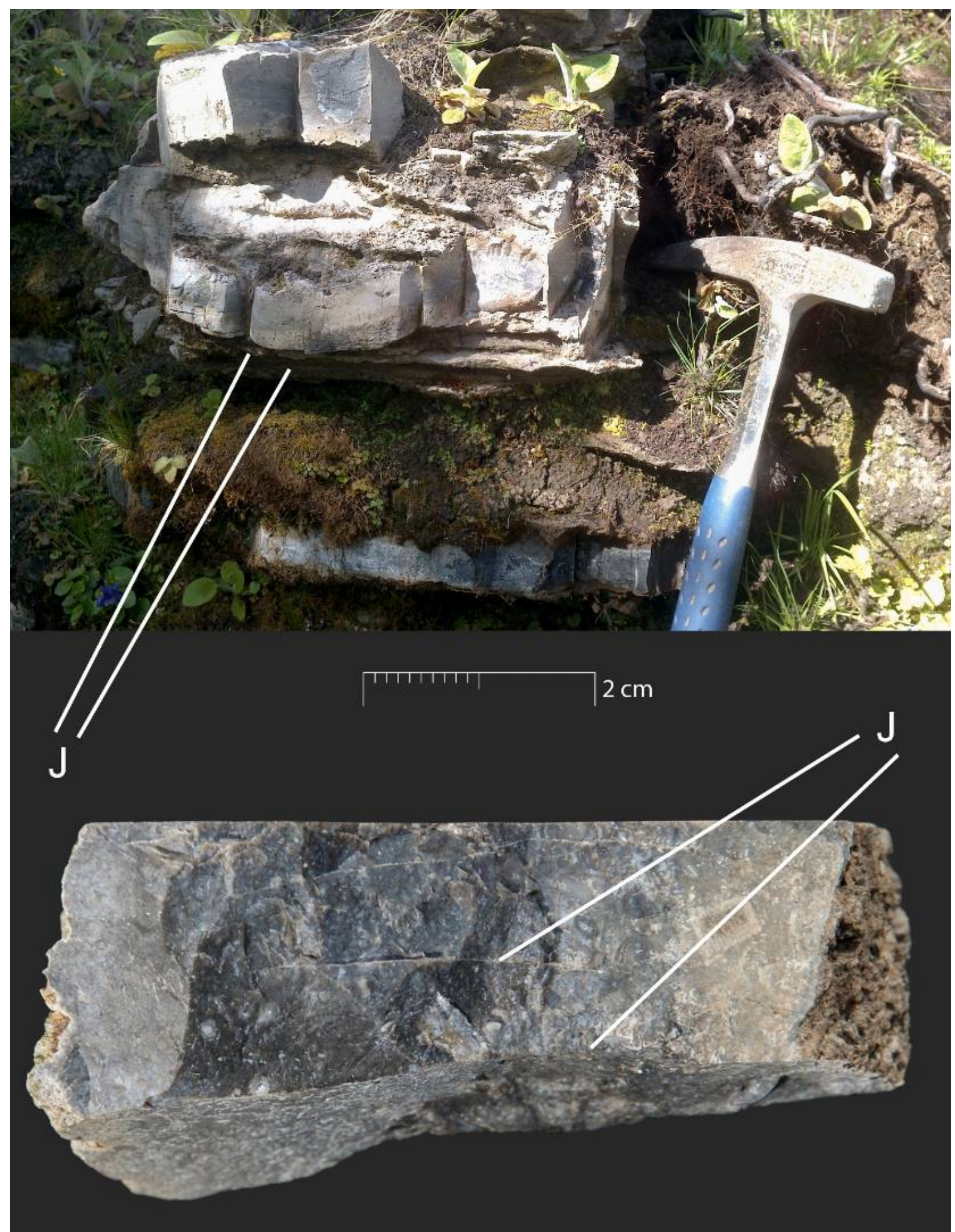

Figure 7. Images taken from the LIR database, with annotations added: $\mathrm{J}=$ joint. Top: example of prevalent, widely spaced joints in Sample IRLL14158 (sample to left of hammer; hammer head is c. $18 \mathrm{~cm}$ wide), from Dartry Limestone Formation, Glasdrumman, County Leitrim; Bottom: example of very prevalent, tightly spaced joints in Sample IRLL14081, from the scree of a modern quarry of the Bricklieve Limestone Formation (lower), Carrickbanagher, County Sligo. Sample IRLL14081 is also an example of the silification gradation within bed, with the sample grading from fine to coarser with fine-grained for c.5cm of centre; IRLL14081 is shown on its side with the top and bottom bedding planes to left and right, and the chert grading horizontally in image. 


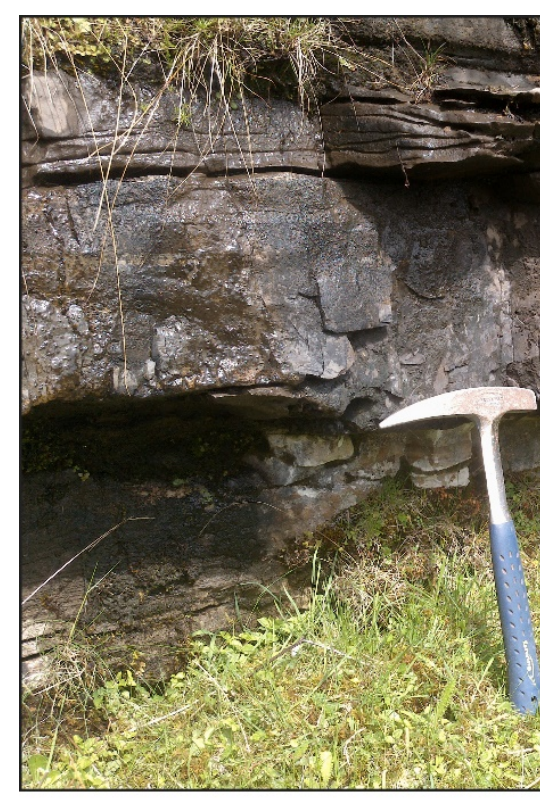

Above: "Sample IRLL14027 (sample above hammer) close-up. Outcrop with chert of Dartry Limestone Formation at Largandoon, Glencar Valley. Facing SE"

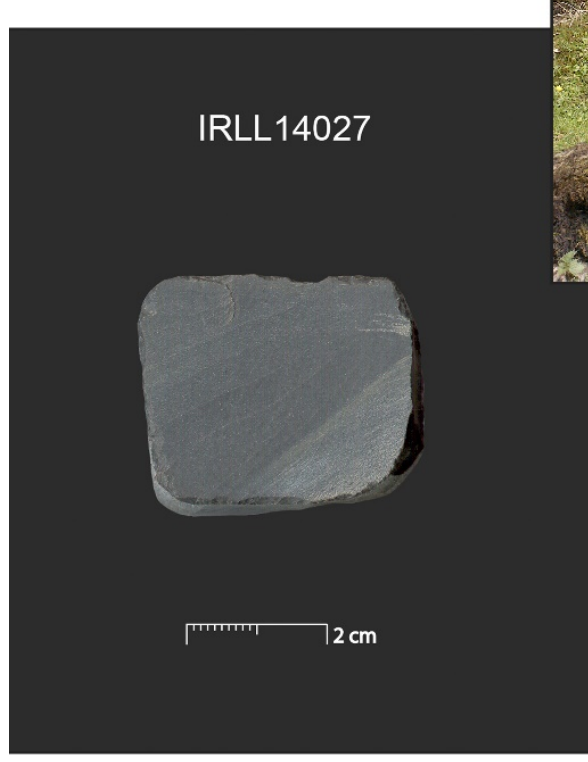

Above: "Geological XRF sample IRLL14027"

Below: "Sample IRLL14027

(sample above hammer) wide shot. Sample IRLL14028 (surficial) collected from stream bed at bottom of image. Outcrop with chert of Dartry Limestone Formation at Largandoon, Glencar Valley. Facing SE"

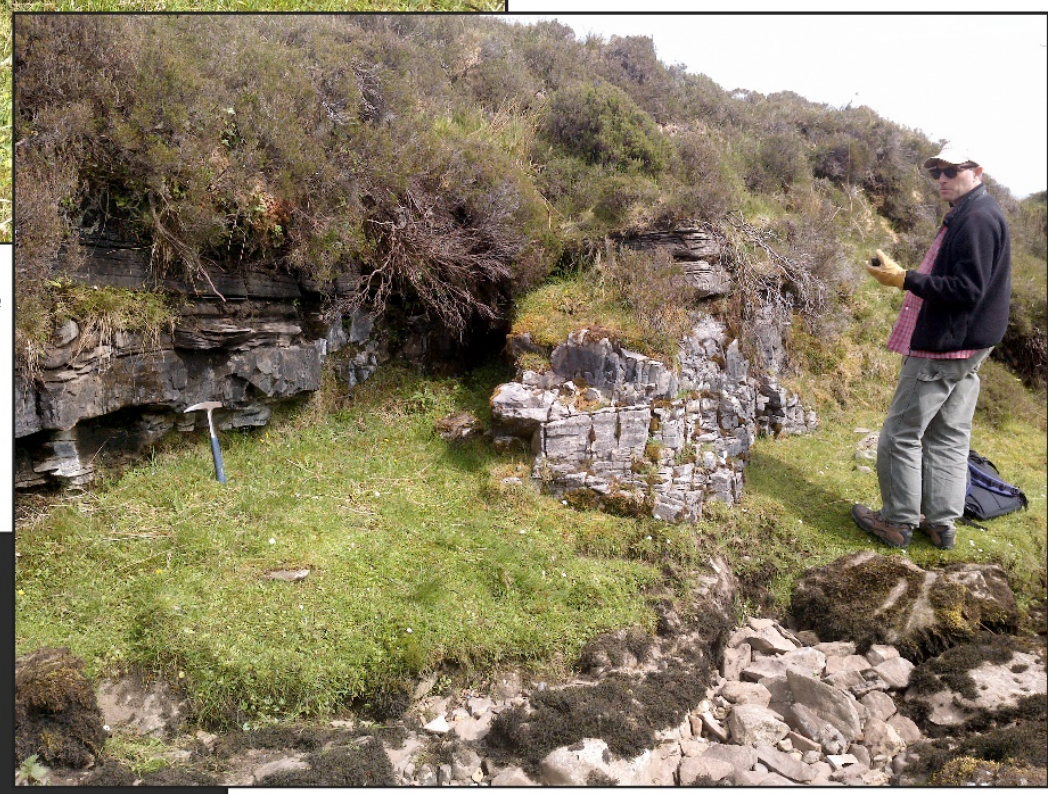

Below: "Geological hand sample IRLL14027"
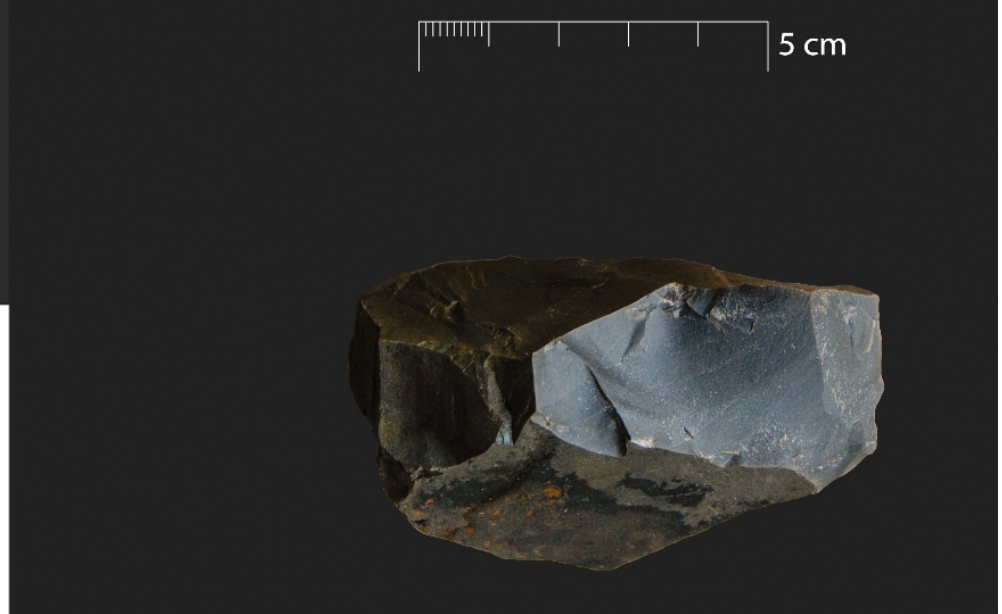

Figure 8. Example of the database images and their captions related to Sample IRLL14027 and Survey point LM015, showing the close-up and wide shot of the sample in the outcrop, and the hand sample and the cut and polished block for XRF. 


\subsubsection{Archaeological Survey points and Samples}

The archaeological Survey points and Samples tables are structured and linked in a similar manner to the geological Survey points and Samples tables, but contain additional data specific to the archaeology. The archaeological survey points are defined as the site the analysed artefacts are from, and include a brief site description and extended site description, the site type, the site dating, a brief description of the lithic assemblage, and an extended description of the lithic assemblage.

The archaeological samples table includes the original artefact name and its habitat (e.g., its Museum habitat, or name of its current holder), the project code identifier that is a prefix based on the project and year followed by a numeric sequence (e.g., IRLLAR14001), the artefact lithic type, a grouping of the artefact into core or debitage, and a technology attribute that describes the direction of the knapping of the artefact if applicable, i.e. knapping parallel or perpendicular to a chert bed or joint surface.

\section{Conclusion}

The LIR (Lithotheque Ireland) reference collection of flaked stone tool raw materials from Ireland is a physical collection of geological hand samples and related thin sections housed at the UCD School of Archaeology, University College Dublin. The physical collection is complemented by an online database that is to be used alongside the physical collection, or can be used as a stand-alone resource. This paper has provided an overview of the database's metadata and the processes of data entry and editing, to serve as a reference point for the database and the fieldwork undertaken to date, and to serve as a template for other researchers undertaking similar work on lithic reference collections.

Worldwide, there is a growing number of archaeologically-focused raw material reference collections with online components (Biró \& Telcs 2000; Burke 2016; Mangado 2016). For the LIR collection and database, one of the objectives was to make all of the data collected over the course of various projects available on the basis of Open Data, thus providing a freely available resource to be used in furthering our understandings of prehistory on the island of Ireland. This data includes that related to the geological prospection and the various analyses of the material such as macroscopic, microscopic - petrographic, and geochemical, and also includes over 2000 images related to these various categories. Along with the geological data, the database includes similar information regarding the archaeological material that is being analysed. Finally, we hope that the 600+ hand samples of flaked stone tool raw materials can be added to over the coming years by both the present research team, as well as other interested researchers.

\section{Acknowledgements}

Killian Driscoll was awarded a Banting Postdoctoral Fellowship, administered by the Government of Canada to undertake the first phase of this project at the Université de Montréal (2013-2015), and the team was awarded a National Geographic Society/Waitt grant for fieldwork for the first season of geological prospection in 2014; for the second phase (2015-2017) at University College Dublin, he was awarded an Government of Ireland Postdoctoral Fellowship administered by the Irish Research Council. Thank you to Dr. Heather Short, geologist, John Abbott College, Quebec, Canada for help during the 2014 geological prospection, and to Dr. Stefan Bergh, National University of Ireland, Galway and Sam Moore, Institute of Technology, Sligo for the guidance around the outcrops and sites of, respectively, Knocknarea and the Carrowkeel and Mullaghfarna group. Thank you to Katherine McCormack and Vincent Hoban, UCD Audio Visual Centre, for their work on 
some of the collection's hand sample images. Thank you to the Irish OpenStreetMap community for their significant work in mapping the boundaries from Ireland and Northern Ireland and making them available as Open Data.

\section{References}

Agafonkin, V. (2016). Leaflet (0.7). URL: http://leafletjs.com/

Biró, K. \& Telcs, G. 2000, LITOTÉKA / A Magyar Nemzeti Múzeum Köeszköz Nyersanyag Gyüjteménye. LITHOTHECA / Comparative Raw Material Collection of the Hungarian National Museum. Retrieved 17/02/2016. URL: http://www.ace.hu/litot/

Burke, A.L. 2016, Lithic collection: Centre de Référence Lithique du Québec (CRLQ). Retrieved 17/02/2016.

URL: http://www.avataq.qc.ca/en/Institute/Departments/Archaeology/OnlineResources/Collections/crlq

Costa, L.-J. \& Sternke, F. 2009, One problem - many solutions: Strategies of lithic raw material procurement in Mesolithic Europe. In: Mesolithic horizons: papers presented at the Seventh International Conference on the Mesolithic in Europe, Belfast 2005 (McCartan, S., Schulting, R., Warren, G.M. \& Woodman, P.C., Eds.), Oxbow Books, Oxford: p. 795-801.

Driscoll, K. 2009, 'They wrought almost any material that came in their way': Mesolithic Flint Alternatives in the West of Ireland. Internet Archaeology, 26. doi:10.11141/ia.26.11

Driscoll, K. 2010, Lithics report for Rathlackan court tomb excavations (E580), Co. Mayo. (Report). Lithics Ireland Consultancy, Galway. 64 p.; Date: 2010.

Driscoll, K. 2011, Vein quartz in lithic traditions: an analysis based on experimental archaeology. Journal of Archaeological Science, 38(3): 734-745. doi:10.1016/j.jas.2010.10.027

Driscoll, K. 2016a, LIR - Lithotheque Ireland. LIR - Lithotheque Ireland. Retrieved 25/05/2016. URL: http://www.lithicsireland.ie/lir.html

Driscoll, K. 2016b, LIR - Surveypoint Master. LIR - Lithotheque Ireland. Retrieved 25 May 2016. URL: http://www.lithicsireland.ie/lir-surveypoint-master.php

Driscoll, K. \& Menuge, J. 2011, Recognising burnt vein quartz artefacts in archaeological assemblages. Journal of Archaeological Science, 38(9): 2251-2260. doi:10.1016/j.jas.2011.03.028

Driscoll, K., Menuge, J. \& O'Keeffe, E. 2014, New materials, traditional practices: a Mesolithic silicified dolomite toolkit from Lough Allen, Ireland. Proceedings of the Royal Irish Academy, Section C, 114: 1-34. doi:10.3318/priac.2014.114.06

EPA 2015, Environmental Protection Agency, Ireland (EPA) Geoportal. Retrieved 14/02/2016. URL: http://gis.epa.ie/

Ferreguti, E. 2014, refFunctions. Retrieved 19/02/2016.

URL: https://plugins.qgis.org/plugins/refFunctions/

GSI 2006a, 1:1,00,000 Bedrock Geology Series. Geological Survey of Ireland. Retrieved 14/02/2016. URL: https://www.gsi.ie/Mapping.htm 
GSI 2006b, 1:100,000 Bedrock Geology Series. Geological Survey of Ireland. Retrieved 14/02/2016. URL: https://www.gsi.ie/Mapping.htm

GSNI 2015, GSNI Digital Geological Map of Northern Ireland - 10k. Retrieved 14/02/2016. URL: https://data.gov.uk/dataset/gsni-digital-geological-map-of-northern-ireland-10kdigmapni-10-metadata

Harvey, P. (2016). Exiftool (10.26). URL: http://www.sno.phy.queensu.ca/ phil/exiftool/

Towns in Ireland, 2016, Townlands in Ireland. Retrieved 19/02/2016. URL: http://www.townlands.ie/

Kador, T. 2007, Where are we going? Movement and Mobility in Mesolithic Research. Internet Archaeology, 22. doi:10.11141/ia.22.2

Little, A. 2009, The Island and the Hill. Extracting scales of sociability from a Mesolithic chert quarry. In: From Bann Flakes to Bushmills: Papers in honour of Professor Peter Woodman (Finlay, N., McCartan, S., Milner, N. \& Wickham-Jones, C.J., Eds.), Prehistoric Society Research Paper Vol. 1, Oxbow, Oxford: p. 133-142.

Little, A. 2010, Tasks, temporalities and textures. Reconstructing the social topography of an Irish Mesolithic lakescape. PhD Thesis at the UCD School of Archaeology, University College Dublin. 256 p.

Luedtke, B.E. 1992, An archaeologist's guide to chert and flint. Archaeological Research Tools Vol. 7. Institute of Archaeology, University of California, Los Angeles. 172 p.

MacAlister, R.A.S. 1949, The Archaeology of Ireland (2nd ed.). Methuen, London. 386 p.

Mangado, X. 2016, LithicUB - Litoteca. Retrieved 17/02/2016. URL: http://www.lithicub.net/

Movius, H.L. 1942, The Irish Stone Age. Cambridge University Press, Cambridge. 378 p.

Ó Ríordáin, A.B. 1967, A Prehistoric Burial Site at Gortnacargy, Co. Cavan. The Journal of the Royal Society of Antiquaries of Ireland, 97: 61-73.

URL: http://www.jstor.org/stable/25509636

OSM 2016, OpenStreetMap. Retrieved 14/02/2016.

URL: https://www.openstreetmap.org/copyright

PostgreSQL (2015). PostgreSQL (9.6): The world's most advanced open source database. URL: https://www.postgresql.org/

QGIS (2014). QGIS (2.6). URL: http://www.qgis.org/

Simms, M.J. 2000, The sub-basaltic surface in northeast Ireland and its significance for interpreting the Tertiary history of the region. Proceedings of the Geologists' Association, 111(4): 321-336. doi:10.1016/S0016-7878(00)80088-7

Warren, G.M., Little, A. \& Stanley, M. 2009, A late Mesolithic lithic scatter from Corralanna, Co. Westmeath, and its place in the Mesolithic landscape of the Irish Midlands. Proceedings of the Royal Irish Academy, Section C, 109: 1-35. doi:10.3318/PRIAC.2009.109.1

Waters, C.N., Somerville, I.D., Jones, N.S., Cleal, C.J., Collinson, J.D., Waters, R.A., Besly, B.M., Dean, M.T., Stephenson, M.H., Davies, J.R., Freshney, E.C., Jackson, D.I., Mitchell, W.I., Powell, J.H., Barclay, W.J., Browne, M.A.E., Leveridge, B.E., Long, S.L. \& McLean, D. 2011, A revised correlation of Carboniferous rocks in the British 
Isles. Geological Society of London Special Report. Vol. 26. Geological Society of London, Bath. 186 p.

Woodman, P.C., Finlay, N. \& Anderson, E. 2006, The archaeology of a collection: The Keiller-Knowles collection of the National Museum of Ireland. Wordwell, Bray. 382 p. 